\title{
Family Ownership and Corporate Environmental Responsibility: The Contingent Effect of Venture Capital and Institutional Environment
}

\author{
Zhu Zhu ${ }^{1}$ and Feifei $\mathrm{Lu}^{2,3, *}$ \\ 1 Department of Management, Feliciano School of Business, Montclair State University, 1 Normal Avenue, \\ Montclair, NJ 07043, USA; zhuz@montclair.edu \\ 2 SILC Business School, Shanghai University, 99 Shangda Road, Shanghai 200444, China \\ 3 Department of Management, School of Business, University of Technology, Sydney, Broadway, \\ NSW 2007, Australia \\ * Correspondence: feifei.lyu@uts.edu.au; Tel.: +86-21-6998-0028
}

Received: 30 April 2020; Accepted: 29 May 2020; Published: 1 June 2020

\begin{abstract}
As scholars and policy makers pay more attention to the environmental impact of economic activities, more focus has been placed on the corporate environmental responsibility (CER) of family firms, which accounts for the majority of businesses in both developed and developing countries. Using a sample of 4714 private enterprises across 23 provinces in China, the current study examines the effect of family ownership on CER investment, as well as the moderating effects of venture capital investment and local institutional development. Results show that concentrated family ownership leads to lower CER spending, however, when venture capital investment comes from developed markets, the negative relationship is reversed. In addition, the marketization level of the province in which a family firm is headquartered mitigates the negative relationship between family ownership and CER investment.
\end{abstract}

Keywords: corporate environmental responsibility; venture capital; institutional development; family ownership; emerging market

\section{Introduction}

The environmental impact of business activities is drawing more attention as scholars and practitioners assess the interactions between the economy and the natural environment. In emerging markets that went through significant institutional reforms and saw tremendous economic growth in the past few decades, one of the key issues under the spotlight revolves around the environmental impact of economic activities (Aguilera et al. 2007; Nekhili et al. 2017). In particular, more focus has been placed on the corporate environmental responsibility (CER) of family businesses, which accounts for the majority of businesses in both developed and developing countries. In the largest emerging market, China, $85 \%$ of all private enterprises are family businesses and more than one-third of publicly traded companies are family owned (Cai 2015). Therefore, family businesses are extremely important when exploring firm behaviors regarding CER.

A recent research effort has begun to focus on publicly listed family firms' CER disclosure behaviors and environmentally friendly governance practices in developed markets (Campopiano and Massis 2015; Nekhili et al. 2017; Rees and Rodionova 2015). However, most family firms are privately held and the internal and external factors that affect the actual amount spent on CER need further investigation, especially in large developing markets, given the environmental crises observed in China and India. From a resource perspective (Arora and Dharwadkar 2011), private family firms may not have the management and financial resources to invest in non-essential activities, taking on voluntary 
environment-friendly initiatives assumes unnecessary economic risk that do not guarantee higher returns. Family firms also tend to prioritize business activities that bring in steady cashflow to ensure high dividend payments (Kappes and Schmid 2013), whereas CER spending is viewed as less important because private family firms are less visible, the reputational risks are lower. In addition, family businesses are usually less formalized; this is especially true prior to initial public offerings (IPOs). It is likely that most private family firms do not have a formal code of ethics regarding environmental responsibility. Overall, private family firms are less likely to voluntarily invest in CER initiatives when ownership is tightly held within the founding family. The current study attempts to fill a gap in the literature by directly examining the effect of family ownership on CER investment in private family firms from a large emerging market.

Although exploring family ownership by looking internally is likely to be fruitful, what happens when external investors come into play? Can foreign venture capital involvement shift family firms' priorities regarding CER and in turn alter their investment decisions? We argue that when family firms welcome venture capital from developed economies with more stable institutional environment into their ownership structure, CER decisions will be influenced. Developed economies have much higher standards when it comes to CER. When venture capital investments come from a more development market, a new set of norms and guidelines on CER related issues will be put into place. As foreign venture capitals increase in ownership, they will have more impact on family firms' decision making. Overall, having venture capital involvement from developed markets represent opportunities for global expansion, the increased competition in the global arena is likely to pressure family firms to improve their CER spending. In the current study, we address a gap in the literature by examining the effect of foreign venture capital involvement on the relationship between family ownership and CER investment. Furthermore, we examine how differences in institutional environment can have differentiated effects on firms' CER activities. From an institutional perspective (Ioannou and Serafeim 2012), firms are constantly influenced by the institutional environment under which they operate. While private family firms may not have formal codes of conduct regarding environmental protection, a higher level of marketization in the local institutional environment may very well provide the support and pressure needed to push for more CER investment. This study aims to explore whether and how the institutional environment affects the relationship between family ownership and CER investment.

This study contributes to the literature in several ways. We offer insights to the literature on corporate environmental responsibility by examining the effect of family business ownership on environmental investment decisions. We argue that tighter family control leads to more firm activities that focus on individual benefits. When there are few external stakeholders involved in management and governance, the reputational and ethical pressure for environmental responsibility is less intense. On the other hand, when external shareholders such as venture capitalists have significant ownership, the pressure increases, thus CER investment goes up. This effect is especially salient when venture investments come from more developed economies that have more vigorous CER related standards and regulations. We also answer the call for research on family business ethics by adapting the agency-stakeholder perspective. We show that family business ownership has a nuanced relationship with CER when venture capitals become internal stakeholders, which improves family owners' ability to pay attention to external stakeholders. Furthermore, we contribute to the growing body of literature that focuses on the institutional environment and its effect on firm behaviors. Family firms often look to their local business community to assess their standards of conduct and determine behavioral norms, when the marketization level of a firm's local environment goes up, the norms of CER spending improves. Family firms that operate in more developed institutional environment will thus receive more support to participate in CER activities and be more closely monitored when making CER-related decisions. 


\section{Theory Development and Hypotheses}

A review of the literature on CER in family firms reveals that scholars have only recently started to focus on factors that affect family firms' reporting and spending on environmental initiatives (Campopiano and Massis 2015; De Massis et al. 2012). Much of the existing literature focuses on family firms' collective good citizen behaviors such as corporate social responsibility (CSR) and environmental, social, and governance (ESG) performance. One group of study examines the differentiated CSR behaviors in family firms with varied value systems and how values influence CSR orientations (Déniz and Suárez 2005; Uhlaner et al. 2004). The importance of value systems regarding CSR decisions are also dependent on the surrounding business community (Niehm et al. 2008) as well as the maturity of the firm (Gómez-Mejía et al. 2007). Family firms that maintain tight governance control and are relatively young do not have much concern for their reputation regarding their social and environmental responsibility, and they do not perceive reputation loss as a big threat due to low visibility (Ding and Wu 2014). Empirical evidence from 3893 firms across 36 countries show that firms with higher family ownership performed worse on CSR indicators on environmental, social, and governance rankings mainly because families in control have very long-term stakes and social/environmental spending may not bring personal benefits (Rees and Rodionova 2015). Another set of studies focuses on comparing family versus non-family firms in terms of CSR behaviors. Some recent findings suggest that family firms primarily make strategic decisions that prioritize family-centered goals and values (Kotlar and Massis 2013), CSR performance is largely influenced by the overall socio-emotional wealth of the family firm (Yu et al. 2015) and the need to perpetuate the family dynasty through intra-family succession often overshadows the prosperity and well-being of stakeholders outside of the family (Bertrand and Schoar 2006; Donckels and Frohlich 1991).

The vast majority of existing studies in the literature are based on publicly listed family firms in developed markets. Some recent studies have focused on the application of the common assessment framework (CAF), which is commonly used in European quality management for the public sector (Popescu et al. 2017), to inform the best practices for investment, performance, and environmental impact. Others have explored the effect of the 2015 United Nations General Assembly Agenda for environmentally sustainable development in European firms (Assimakopoulos et al. 2020; Szopik-Depczyńska et al. 2018). Although listed firms provide more readily available information regarding CSR reporting, ESG performance ranking, and CER spending, it is likely that the visibility of being a listed firm has significant influence. In addition, developed markets tend to have more formal codes and regulations regarding environmental impact, the differences in CER are often driven by changes in laws and the pressure to reach behavioral standards amongst industry rivals. Given that most family businesses are privately owned and the environmental consequences of business activities are especially salient in emerging markets, the current study aims to address this research gap and explore the CER activities of private family firms in a large emerging economy, especially when foreign venture capital investments come into play, and when there are differentiated levels of institutional development across regions.

We choose China as our research context because despite recent efforts to curb pollution and improve environmental management across industries, China remains one of the biggest polluters on all key metrics. Moreover, there are over 20 million private Chinese family businesses and China has $38 \%$ of global venture spending. We are able to draw on recent studies that examine firm behavior via institutional contingencies (Shi et al. 2012) to contribute to the growing family business literature and venture capital literature that focus on the emerging market. Lastly, China has a large number of sub-national regions (provinces) that exhibit a highly diverse institutional landscape (Shi et al. 2012, 2017). This makes it possible for us to explore country institutional variance and its effect on family firm CER investment.

\subsection{Family Private Ownership and CER Investment}

In both developed and developing markets, family ownership is the most common ownership structure. Family owners tend to be very long term oriented when making investment decisions and 
the governance composition is usually concentrated within the family. According to studies applying agency theory in the family business context and drawing from the agency-stakeholder perspective (Hill and Jones 1992), private family firms incur unique agency costs such as inefficient governance, hiring lower quality agents due to limited labor pool, and paying less attention to external stakeholders (e.g., environment, community, general public) (Schulze et al. 2001). Since family firms strive to achieve both financial goals and socio-emotional wealth (SEW), which includes non-economic and emotional aspirations (Gomez-Mejia et al. 2011), conflict of interests may arise because non-financially driven goals can cause managers to make irrational decisions that are not beneficial to themselves nor other stakeholders. This "agency problem with one-self" (Jensen 2001, p. 48) is more prevalent in privately held family firms because the owners have a tight grip over all key decisions and are able to indulge in actions based on personal priorities. For example, a family chief executive officer (CEO) may choose to not participate in initiatives that benefit the environment because he or she would rather use the money to support a relative's new venture, even if the environmental initiatives are likely to generate reputational and long-term cost saving benefits. This type of irrational decision is more common in privately held family firms because family owners have the urge to satisfy family members' needs and have power over the firm's resources to do so (Lubatkin et al. 2007). The personal-interests and family-related aspirations often take precedence over other interests, even if they may be better business decisions, which exacerbates family firms' self-control problem (Becker and Murphy 1988; Schulze et al. 2001).

For private family firms, the decision to invest in CER is also influenced by the ethical tendencies and perceptions of family managers. Regarding ethics in family firms, some argue that family firms can be less ethical in some ways when compared to other firms (Adams et al. 1996). This view is largely based on the phenomenon that family firms tend to be much less formalized than other firms, which means that many family firms do not have a formal code of ethics regarding external stakeholders and environmental impacts. In the case of private family firms that have undiversified management teams, the primary aspirations mostly revolve around building socio-emotional wealth and "passing the baton" to successors found within the family (Gómez-Mejía et al. 2007). While many family business owners are well aware that external professional managers may be better equipped to lead the company to future prosperity and longevity, the majority of family firms still strongly prefer intra-family succession plans (Casson 1999; Schulze et al. 2001). Some argue that many ethical violations in family businesses stem from nepotism and an overall lack of professionalism, which fosters self-interested organizational climate (Gallo 1998; Duh et al. 2010). Coupled with low visibility and minimal need for obtaining consensus and approval amongst external stakeholders, private family firms are likely to have more concerns for the well-being of the family members personal benefits and the firm's essential needs, especially when CER related investments are not perceived to generate tangible returns.

In particular, family firms with ownership structure that is heavily concentrated within the family will exhibit more self-focused behaviors and ignore investments that do not bring personal benefits (Rees and Rodionova 2015). High family ownership also indicates that there is a lack of managerial diversity and the key decision makers are likely to have consensus regarding using firm resources mostly for family centric needs. With limited external pressure and information, private firms with high family ownership are less attuned to the behavioral norms and CER standards in other firms in the greater business community. Business decisions that put their own family members' personal interests first in this type of situation are more justified and perhaps deemed more ethical, compared to investing in the well-being of the external environment, which is often far removed from the most essential needs of the inner circle. Family firms that maintain their ownership are also more likely to perceive a lack of managerial and financial resources to waste on non-essential business activities. The focus on preserving family wealth can also create an echo chamber within local family firm communities, which makes it difficult for individual firms to accurately assess the cost/benefit of CER investment. These factors all contribute to roadblocks for promoting investment decisions towards CER. Therefore, we argue that private family firms tend to spend less on CER when ownership is concentrated within the family. 
Hypothesis 1. The percentage of family ownership is negatively related to CER investment.

\subsection{Effect of Foreign Venture Capital on Family Private Ownership and CER}

Although family ownership is arguably one of the most important factors that influence family firm investment decisions, many firms do not consistently maintain full ownership. In order to obtain sustainable growth and further product development, many family firms turn to venture capital and private equity investments for the added financial and managerial resources. From a family firm's perspective, outside investors provide concrete solutions to funding issues revolving growth plans, acquisition intentions, succession, and preservation of independence from bigger players in the industry (Corbetta 1995; Dawson 2011). However, when outside investors become involved, the family no longer has complete control over the governance and decision making of the firm. Existing literature shows that institutional investors play a key role in driving socially and environmentally responsible behaviors in invested firms ( $\mathrm{Li}$ et al. 2020). When firms receive investments from foreign investors with strong CSR norms, their own subsequent social performance are likely to improve (Dyck et al. 2019). Therefore, a key research question arises: Does the presence of outside investor alter private family firms' investment decisions regarding CER? To answer this question, it is crucial to examine the outside investors' effect on family firm ownership dynamics and the institutional standards regarding CER from the investor's host country. The current study focuses on foreign venture capital investments from developed markets.

When venture capital investments dilute the dominance of family ownership, the concentration of family decision power inevitably decreases. Family firms with concentrated equity pay more attention to internal stakeholders than regulatory and market stakeholders when it comes to environmental management (Huang et al. 2009). With the addition of foreign venture capital investments, external CER pressure from consumers, competitors, regulatory agencies, and environmental protection laws will become more salient. Venture capital institutions also provide valuable guidance on good governance practices and often help family firms implement monitoring and advising mechanisms such as board of directors, audit committees, and third-party review processes. These governance strategies alleviate the issue of "agency problem with one-self" (Jensen 2001, p. 48) by providing managerial expertise and formal governance structure to prevent family managers from making irrational and self-serving business decisions.

In addition to improving managerial diversity, venture capital investments, especially when coming from developed markets, often set new norms and baselines for CER related issues. In a large emerging market like China, there has been unparalleled levels of economic expansion in the past two decades. Unfortunately, the rapid economic growth has been accompanied by a concerning level of pollution, making China one of the largest polluters in the world. Compared to developed economies, China does not have a very high standard when it comes to controlling pollution in newly built industrial plants. Evidence suggests that foreign owned manufacturing firms in China exhibit less pollutant emissions than wholly owned Chinese firms (Jiang et al. 2014). Foreign enterprises from developed markets tend to use cleaner energy and invest more on energy efficiency (Harrison and Eskeland 2003), and they worry more about reputational risks associated with environmental management (Wang and Jin 2002). Therefore, it is possible that venture capitalists from developed markets will have a similar impact on family firms in China, insofar that they are likely to provide more advanced environmental management expertise, as well as enforce an elevated level of CER standards. Venture capitalists from developed markets represent opportunities for global expansion and next level growth, the increased level of competition in the global arena will place more pressure on family firms to raise their bar on CER initiatives. By taking on venture capital investment from developed markets, private family firms must adapt to the international behavioral norms when it comes to CER. Having concentrated family ownership in this situation will actually push top managers to pay extra attention to CER and more easily make concerted efforts towards CER initiatives. Therefore, we argue that not only do venture capital investments improve CER investment, the prevalence of foreign investments will drastically mitigate the negative relationship between family ownership and CER spending. 
Hypothesis 2. Foreign venture capital investment from developed markets negatively moderates the negative relationship between family ownership and CER investment.

\subsection{Impact of Institutional Environment on Family Ownership and CER}

Although examining the effect of venture capital investment from developed markets can shed light on how CER standards from foreign institutions can influence family businesses in an emerging market like China, it is important to take a closer look at the potential variance in institutional environment within China. One key characteristic of the Chinese institutional environment that differs from developed markets lies in its lack of consistency and stability. In particular, for the past two decades, China has undergone drastic marketization efforts, and local governments are adapting to the open market trend at different paces. The CER standards around China vary across provinces and the regulatory framework around the country have improved at different rates (Shi et al. 2017). Consequently, some provinces have more comprehensive institutional support and stricter monitoring mechanism in place for CER-related issues. For example, the rapid increase in urbanization in China is inevitably matched by drastic increase in energy demand, especially in the northern region. Energy efficiency and pollution standards are difficult to reach for many family firms (Yin et al. 2020). The ability for firms to make CER investments is often constrained by the level of support provided by the local governments, as well as financial incentives in the form of grants and tax benefits. A similar phenomenon is observed in developing countries in Europe, where firms operate in environmentally sustainable manners if they have the financial literacy and receive sufficient institutional support (Popescu and Popescu 2019). Therefore, the differentiated levels of institutional development across China add to the complexity and uniqueness of family firms' CER behaviors.

The Chinese context of our study is both timely and important. Answering the call for context driven business research that shifts away from assuming an institutional void (Cuervo-Cazurra and Dau 2009), and instead focuses on institutional differences within an emerging market (Shi et al. 2017). Examining the relationship between family ownership and CER investment must consider the external institutional environment as a contingency mechanism in a large, dynamic emerging economy such as China. Our study examines the contingent effect of family ownership on CER decisions under different levels of sub-national marketization, which is one of the most important characteristics in an emerging economy (Davies and Walters 2004; Fan et al. 2007). The differentiated marketization levels between provinces across China provide an opportunity to examine the effect of the external institutional environment on shaping family firms' CER activities. This is only possible in large emerging economies that has tens of millions of family businesses while exhibiting observable variances in institutional development.

Marketization is defined as the process of transforming a national economy into a market-oriented economy (Fan et al. 2007). Although scholars have traditionally focused on cross-country differences (Coughlin et al. 1991), sub-national or within-country institutional differences has become a topic of interest in recent business literature (Chan et al. 2010). Although large developed economies such as the United States have sub-national institutional differences (Shaver and Flyer 2000), these differences are much more noticeable and idiosyncratic in large emerging economies (Chan et al. 2010). When a family firm is headquartered in a province with higher degrees of marketization, the local government and surrounding institutions are much more likely to provide guidance and supports when it comes to CER initiatives. In many cases, there are more regulations that force both private and public enterprises to comply with industry standards regarding to minimizing impact to the natural environment. The behavioral norms within the family firm communities will also have an elevated level of recognition and acknowledgement regarding the necessity of CER investment. Although private family firms with tight ownership control still have all the decision power, in provinces with a high level of marketization, the attention on environmental issues are more salient and the regulatory institutions are more competent in monitoring and controlling CER related behaviors. Therefore, we argue that the institutional environment plays a key role in understanding the relationship between family ownership and CER decisions. 
Hypothesis 3. The marketization level of the province in which the family firm is headquartered negatively moderates the negative relationship between family ownership and CER investment.

\section{Methods}

\section{Sample and Data}

The data we used in this study consists of privately held family firms in China. Two sources were used to construct the final sample. First, we used data from a survey of Chinese privately-owned enterprises (POEs) conducted by the privately-owned enterprises research project team (POERPT) in 2016 (Jia 2014). In this survey, the research team first generated a nationwide random sample of POEs using multistage stratified sampling across all provinces and industries and then used a questionnaire to conduct direct interviews with the majority owner of each POE represented in the sample. The research team members are scholars from a wide range of governmental institutions and NGOs. The surveys were conducted for an ongoing national project that sought to collect private sector information to facilitate the Chinese government policy making processes (Jia 2014).

The second source of data focused on sub-national institutional data. We obtained province-level marketization data from the National Economic Research Institute's (NERI) index of market development of Chinese provinces (Fan et al. 2011). The NERI index of marketization captures the multiple dimensions of institutional reform across provinces and years. The dimensions include: (1) business-government interfaces; (2) development of private firms; (3) development of product markets; (4) development of factor markets; and (5) development of market and legal intermediaries.

The two databases included in the current research are commonly used in prior research on Chinese firms (Fan et al. 2011; Jia 2014; Sun et al. 2016). The final sample of 4714 observations comprises of private firms from 23 provinces in China. The CEOs of these private firms were on average 46 years old and Firm age ranged from 1 to 43 years.

\section{Measures}

\subsection{Dependent Variable: Corporate Environmental Rresponsibility Investment}

Following the research of Lin et al. (2007), we considered anti-pollution investment as the key indicator of CER investment. Thus, we used the firm's investment amount on anti-pollution to measure CER investment.

\subsection{Independent Variable: Family Ownership}

We used the percentage of stock owned by family members to measure family ownership (Anderson and Reeb 2003), with a larger value indicating greater family ownership interests in the firm (Wang 2006).

\subsection{Moderating Variables}

\subsubsection{Foreign Venture Capital}

Different from previous studies only used dummy variable to measure foreign venture capital (e.g., Pruthi et al. 2003), we used the ratio of foreign venture capital to measure foreign venture capital to address the differences among foreign venture capital firms.

\subsubsection{Marketization Level}

We used the NERI index of marketization in Chinese provinces to measure the quality of regional marketization level (Fan et al. 2011). This index has been established by NERI for more than a decade and is widely utilized by previous scholars to examine China's regional institutions (Shi et al. 2017). The NERI index examines the quality of market-supporting institutions in different Chinese provinces 
with five dimensions including market intermediaries and legal environment, product market, the factor market, the development of the private economy, and also the relationship between the government and market (Sun et al. 2016). An overall NERI index is calculated by a weighted average of the scores in the five dimensions. Following the research (Sun et al. 2016), we matched the index with sample firms in the provinces in which they were located.

\subsection{Control Variables}

We also included control variables in our model, including firm-level variables (i.e., age, size, political ties, and sales performance) and the CEOs' demographic variables (i.e., gender, age, and education level). For firm-level variables, we measured firm size with the logarithm of the number of employees (Guthrie and Olian 1991). We also included firm sales performance, measured by the volume of annual sales. We also controlled firm's political ties, which reflects a firm's institutional pressure to conduct CER. Following prior studies on firm-level political ties (Li et al. 2008; Shi et al. 2014), we measure a firm's political ties as a dummy variable. We coded " 1 " if current CEO is a member of the Chinese Communist Party and "0" otherwise. We also controlled for the demographic variables of the incumbent CEOs, including age, gender (Harveston et al. 1997), education level, and study abroad experiences. We controlled for the effects of the CEO's study abroad experience because research has indicated that CEO's international experiences affect corporate social performance (Slater and Dixon-Fowler 2009).

To address the potential endogeneity problem driven by unobservable CEO and family characteristics, we have controlled for three additional variables in the revised manuscript. First, we controlled for family firms' internal succession intention to rule out the influence of family firms' long-term orientation on CER investment. Family firms that aimed to maintain family control through successions are more likely to invest in CER due to the influence of long-term orientation (Block 2010; Block and Wagner 2010). Graafland and Smid (2004) also demonstrated the positive influence of long-term orientation and CSR. Thus, we believe that the family firm's internal succession intention is an appropriate proxy variable of the family firm's CER orientation. Second, we controlled for the effects of the CEO's social status on CER to rule out the influence of CEO's CER orientation in our research model. CEOs with high social status may have a high need for attention and praise as well as a strong desire to have their positive self-views reinforced, which has been shown to affect CEO decision making such as CER (Chatterjee and Hambrick 2007; Gerstner et al. 2013). We measured the CEO's social status by using the MacArthur Scale of subjective social status (1-10 rating scale), which is a global measure of subjective social status and is related to the individual's place in the social hierarchy (Ghaed and Gallo 2007). Finally, we controlled for the effects of brand reputation on CER to rule out the influence of corporate reputation on foreign investment. The brand reputation of the company was measured by collecting CEOs' responses to the following question: "Compared with competitors in the industry, do you have a brand competitive advantage?"

\section{Data Analysis}

We performed hierarchical regression analyses to test the hypotheses with SPSS 22.0. To minimize multicollinearity, family ownership, foreign venture capital, and marketization level were standardized prior to the regression analyses. We entered the variables into the regression models through four hierarchical steps: (1) the control variables; (2) the main effect variable: family ownership; (3) the moderators: foreign venture capital and marketization level; and (4) two-way interaction terms. The presence of multicollinearity was assessed in each regression model. The values of the variance inflation factor (VIF) were all below 3.0, which ruled out multicollinearity (Neter et al. 1985).

\section{Results}

Table 1 presents the descriptive statistics and correlations among the study variables. Table 2 shows the results of the hierarchical regression analyses. Figure 1 shows the interaction plots of family 
ownership and foreign venture capital. Figure 2 depicts the interaction plots of family ownership and marketization level.

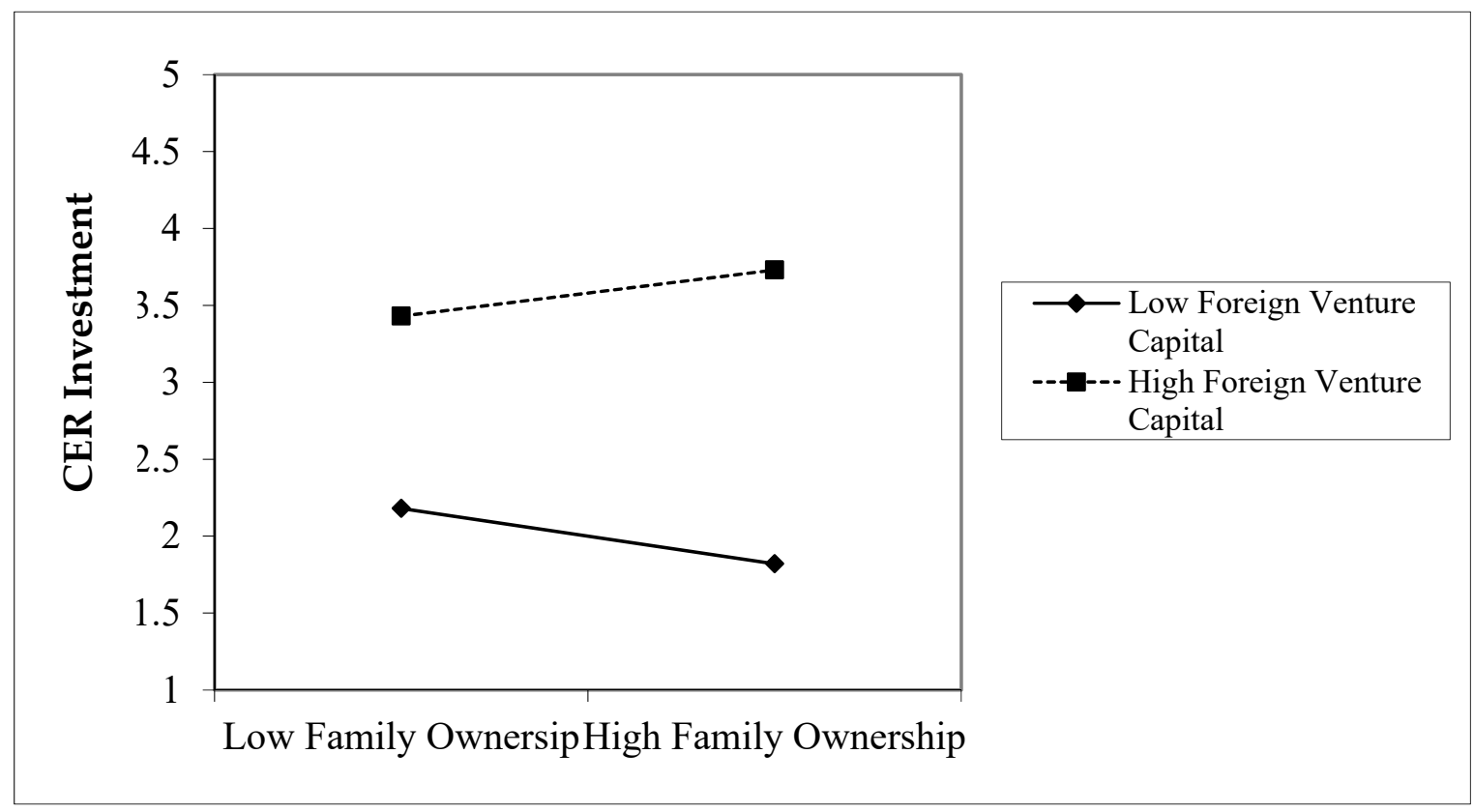

Figure 1. Interaction plots of family ownership, foreign venture capital, and corporate environmental responsibility (CER) investment.

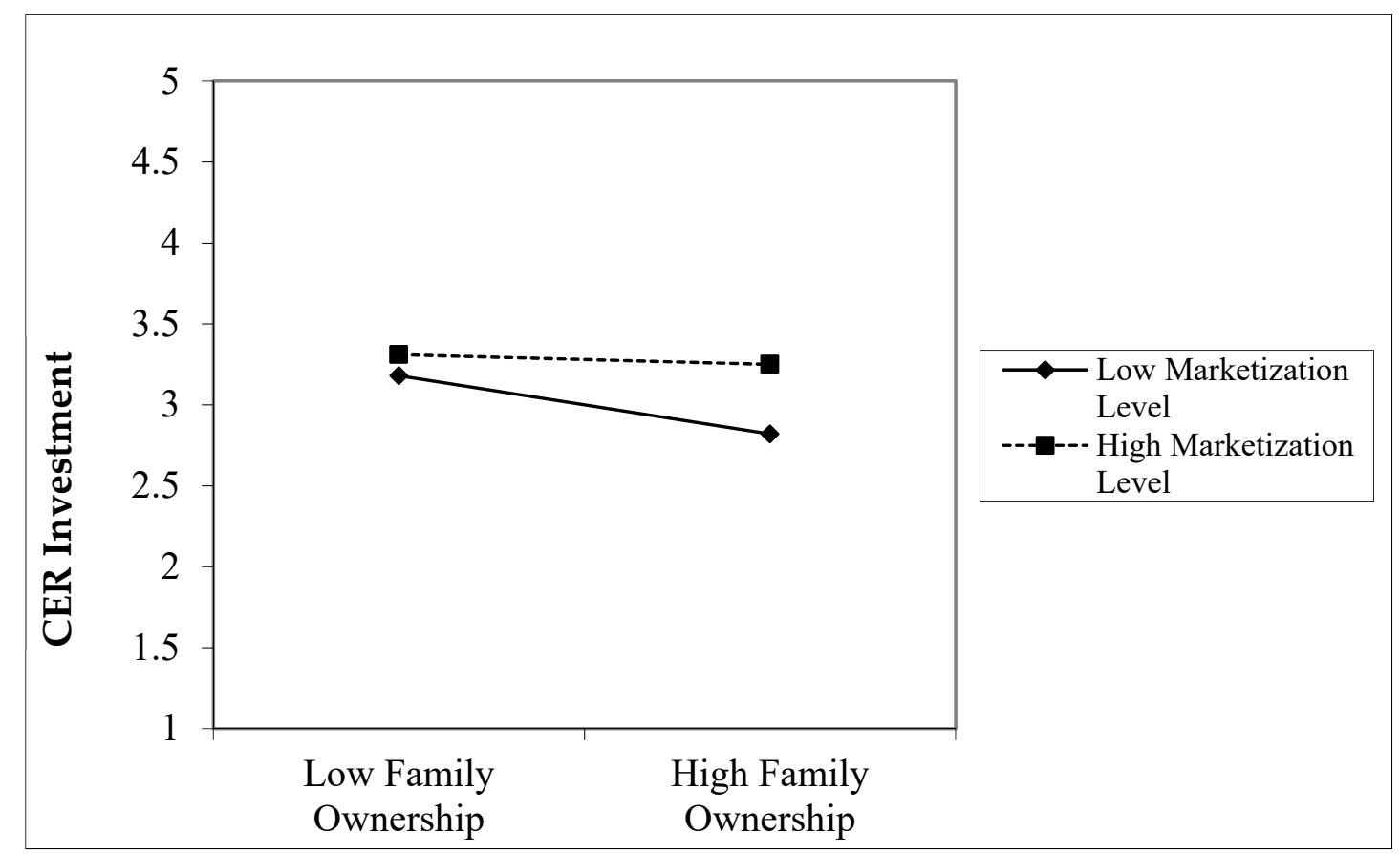

Figure 2. Interaction plots of family ownership, marketization level, and corporate environmental responsibility (CER) investment. 
Table 1. Descriptive statistics and correlations. CEO: chief executive officer.

\begin{tabular}{|c|c|c|c|c|c|c|c|c|c|c|c|c|c|c|c|c|}
\hline Variables & Mean & SD & 1 & 2 & 3 & 4 & 5 & 6 & 7 & 8 & 9 & 10 & 11 & 12 & 13 & 14 \\
\hline 1. CEO gender & 0.81 & 0.40 & & & & & & & & & & & & & & \\
\hline 2. CEO age & 46.39 & 9.49 & $0.13^{* *}$ & & & & & & & & & & & & & \\
\hline 3. CEO education level & 2.81 & 1.09 & 0.02 & $-0.19^{* *}$ & & & & & & & & & & & & \\
\hline 4. CEO's foreign study experience & 0.10 & 0.30 & 0.02 & $-0.04 * *$ & $0.19^{* *}$ & & & & & & & & & & & \\
\hline 5. CEO's social status & 5.85 & 1.90 & $-0.11^{* *}$ & $-0.18^{* *}$ & $-0.15^{* *}$ & $-0.12 * *$ & & & & & & & & & & \\
\hline 6. Firm age & 13.99 & 8.29 & $0.13^{* *}$ & $0.48^{* *}$ & 0.01 & $0.03 *$ & $-0.27 * *$ & & & & & & & & & \\
\hline 7. Firm size & 196.11 & 1773.80 & 0.02 & $0.04 *$ & $0.09 * *$ & $0.07^{* *}$ & $-0.07 * *$ & $0.08 * *$ & & & & & & & & \\
\hline 8. Political tie & 0.27 & 0.44 & $0.14^{* *}$ & $0.20^{* *}$ & $0.14^{* *}$ & $0.03 *$ & $-0.18^{* *}$ & $0.17^{* *}$ & $0.04 *$ & & & & & & & \\
\hline 9. Firm sales & 113.22 & 3976.30 & $-0.04 * *$ & 0.01 & 0.01 & 0.01 & 0.01 & 0.02 & 0.01 & -0.01 & & & & & & \\
\hline 10. Succession intention & 0.14 & 0.35 & $0.05^{* *}$ & $0.28^{* *}$ & -0.06 ** & 0.01 & $-0.15^{* *}$ & $0.23 * *$ & 0.03 & $0.09 * *$ & $0.03 *$ & & & & & \\
\hline 11. Brand reputation & 0.18 & 0.38 & $0.05^{* *}$ & $0.06^{* *}$ & $0.09 * *$ & $0.04 * *$ & $-0.12 * *$ & $0.14^{* *}$ & 0.02 & $0.05^{* *}$ & -0.01 & $0.05^{* *}$ & & & & \\
\hline 12. Family ownership & 0.85 & 0.28 & -0.05 ** & $-.06^{* *}$ & $-0.15^{* *}$ & $-0.04 *$ & $0.05 * *$ & $-0.04 * *$ & $-0.07 * *$ & $-0.10^{* *}$ & 0.01 & $0.06^{* *}$ & $-0.04 * *$ & & & \\
\hline 13. Foreign Venture Capital & 0.01 & 0.06 & 0.02 & $0.05^{* *}$ & $0.04 * *$ & 0.02 & $-0.03 * *$ & $0.05^{* *}$ & $0.04^{* *}$ & $0.03 *$ & -0.01 & 0.02 & 0.01 & $-0.20 * *$ & & \\
\hline 14. Marketization level & 7.44 & 1.73 & $0.05^{* *}$ & $0.10^{* *}$ & $0.12 * *$ & $0.09^{* *}$ & -0.12 ** & $0.15^{* *}$ & $0.06 * *$ & 0.04 ** & 0.01 & 0.06 ** & 0.01 & $-0.04 *$ & $0.03 *$ & \\
\hline 15. CER investment & 3.37 & 5.43 & $0.11^{* *}$ & $0.18^{* *}$ & $0.13^{* *}$ & $0.07^{* *}$ & $-0.25 * *$ & $0.30^{* *}$ & $0.11^{* *}$ & $0.19^{* *}$ & 0.02 & $0.15^{* *}$ & $0.10^{* *}$ & $-0.10^{* *}$ & $0.15^{* *}$ & $0.12 * *$ \\
\hline
\end{tabular}

$N=4714 ; * p<0.05 ; * * p<0.01$ 
Table 2. Regression model.

\begin{tabular}{|c|c|c|c|c|c|c|c|c|}
\hline \multirow{2}{*}{$\begin{array}{l}\text { Variables } \\
\text { Controls }\end{array}$} & \multicolumn{2}{|c|}{ Model 1} & \multicolumn{2}{|c|}{ Model 2} & \multicolumn{2}{|c|}{ Model 3} & \multicolumn{2}{|c|}{ Model 4} \\
\hline & B & SE & B & SE & B & SE & B & SE \\
\hline CEO gender & $0.64^{* * *}$ & 0.19 & $0.61^{* *}$ & 0.19 & $0.59 * *$ & 0.19 & $0.59 * *$ & 0.19 \\
\hline CEO age & $0.02 *$ & 0.01 & 0.01 & 0.01 & 0.01 & 0.01 & 0.01 & 0.01 \\
\hline CEO education level & $0.50^{* * *}$ & 0.07 & $0.45^{* * *}$ & 0.07 & $0.41^{* * *}$ & 0.07 & $0.42^{* * *}$ & 0.07 \\
\hline CEO's foreign study experience & 0.20 & 0.25 & 0.20 & 0.25 & 0.14 & 0.25 & 0.13 & 0.25 \\
\hline CEO's social status & $-0.39^{* * *}$ & 0.04 & $-0.39^{* * *}$ & 0.04 & $-0.38^{* * *}$ & 0.04 & $-0.37^{* * *}$ & 0.04 \\
\hline Firm age & $0.13^{* * *}$ & 0.01 & $0.13^{* * *}$ & 0.01 & $0.13^{* * *}$ & 0.01 & $0.12^{* * *}$ & 0.01 \\
\hline Firm size & $0.01^{* * *}$ & 0.01 & $0.01^{* * *}$ & 0.01 & $0.01^{* * *}$ & 0.01 & $0.01^{* * *}$ & 0.01 \\
\hline Political tie & $1.14^{* * *}$ & 0.18 & $1.09 * * *$ & 0.18 & $1.10^{* * *}$ & 0.18 & $1.09^{* * *}$ & 0.18 \\
\hline Firm sales & $3.03 \times 10^{-9 *}$ & 0.01 & $3.06 \times 10^{-9 *}$ & 0.01 & $3.11 \times 10^{-9 *}$ & 0.01 & $3.10 \times 10^{-9 *}$ & 0.01 \\
\hline Succession intention & $1.07^{* * *}$ & 0.23 & $1.16^{* * *}$ & 0.23 & $1.11^{* * *}$ & 0.23 & $1.11^{* * *}$ & 0.23 \\
\hline Brand reputation & $0.43 *$ & 0.20 & $0.41 *$ & 0.20 & $0.45^{* *}$ & 0.20 & $0.44 *$ & 0.20 \\
\hline \multicolumn{9}{|l|}{ Main effects } \\
\hline Family ownership & & & $-0.38^{* * *}$ & 0.08 & $-0.26^{* * *}$ & 0.08 & $-0.24^{* *}$ & 0.08 \\
\hline \multicolumn{9}{|l|}{ Moderator } \\
\hline Foreign Venture Capital & & & & & $0.77^{* * *}$ & 0.10 & $1.48^{* * *}$ & 0.34 \\
\hline Marketization level & & & & & $0.29^{* * *}$ & 0.08 & $0.27^{* * *}$ & 0.08 \\
\hline \multicolumn{9}{|l|}{ Interaction terms } \\
\hline Family ownership $\times$ Foreign Venture Capital & & & & & & & $0.28 *$ & 0.13 \\
\hline Family ownership $\times$ Marketization level & & & & & & & $0.16^{*}$ & 0.08 \\
\hline Constant & 0.45 & 0.60 & 0.81 & 0.60 & $1.15^{*}$ & 0.60 & $1.21 *$ & 0.60 \\
\hline R square & \multicolumn{2}{|c|}{0.161} & \multicolumn{2}{|c|}{0.166} & \multicolumn{2}{|c|}{0.180} & \multicolumn{2}{|c|}{0.182} \\
\hline Adjusted R square & \multicolumn{2}{|c|}{0.159} & \multicolumn{2}{|c|}{0.163} & \multicolumn{2}{|c|}{0.178} & \multicolumn{2}{|c|}{0.179} \\
\hline $\mathrm{R}$ square change & \multicolumn{2}{|c|}{$0.161 * * *$} & \multicolumn{2}{|c|}{$0.004^{* * *}$} & \multicolumn{2}{|c|}{$0.014^{* * *}$} & \multicolumn{2}{|c|}{$0.002 *$} \\
\hline
\end{tabular}

$N=4714 ;{ }^{*} p<0.1$ ** $p<0.05 ;{ }^{* *} p<0.01 ;{ }^{* * *} p<0.001$. 
Hypothesis 1 proposes that the percentage of family ownership relate negatively to CER investment. As shown in Table 2 , the main effect of family ownership $(\beta=-0.38, p<0.001)$ on CER investment is significant and negative. Thus, the main effect hypothesis is supported.

In terms of the interaction between family ownership and foreign venture capital, we propose that foreign venture capital will negatively moderate the negative relationship between family ownership and CER investment (Hypothesis 2). The interaction term family ownership $\times$ foreign venture capital in Table 2 in model 4 is significant and positive $(\beta=0.28, p<0.05)$, so Hypothesis 2 is supported. Hypothesis 3 proposes that marketization level negatively moderate the negative effects of family ownership on CER investment. The interaction term family ownership $\times$ marketization level in Table 2 in model 4 is marginally significant and positive $(\beta=0.16, p<0.1)$, which provides moderate support for Hypothesis 3.

Recalling results for Hypothesis 2, when family firms have foreign venture investment, family firms are more likely to invest on CER. To investigate the moderating effect of foreign venture capital, we generate Figure 1 based on model 4 of Table 2. The interaction plots in Figure 1 suggest that the ratio of foreign venture capital negatively moderates the relationship between the percentage of family ownership and CER investment. Figure 1 shows that the negative effects of family ownership on CER investment is more significant when the foreign venture capital is low. The negative influence of family ownership on CER investment is weakened when the foreign venture capital is high. Therefore, Hypothesis 2 is strongly supported.

The interaction plots in Figure 2 suggest that the marketization level negatively moderates the relationship between the percentage of family ownership and CER environment. Hypothesis 3 proposes that, when the institutional environment is less developed, family firms are less likely to invest on CER because these firms receive less institutional support and do not feel as much pressure from their external legal environment regarding CER. Due to weak market-supporting institutions, private family firms are more likely to rely on political connections and invest money on establishing good relationships with government rather than green innovation. In a formal and legal environment, government may also fine those private firms who violate the environmental regulations and encourage them to invest more on CER, thus weakens the negative effects of family ownership on CER investment. Figure 2 shows that the negative effects of family ownership on CER investment is more significant when the marketization level is low. While the negative relationship between family ownership and CER investment is not reversed, it is weakened when the marketization level is high, which is consistent with the proposition in Hypothesis 3. Therefore, Hypothesis 3 receives some support.

\section{Discussion and Conclusions}

Motivated by the call for research on factors that influence family firms' CER behaviors (Campopiano and Massis 2015), the current study explores (1) the effect of family ownership on CER activities in private Chinese family firms and (2) the moderating effect of venture capital investment from developed markets, as well as (3) the role of institutional development variance across provinces. Our results show that family ownership is negatively related to CER investments, which suggests that private family firms with tight ownership control are less likely to spend on CER when compared to firms with less concentrated ownership structure. Our results also show that when venture capital investments come in from developed markets, the aforementioned negative relationship is reversed. This means that when taking on venture capital investment from developed markets, private family firms must adapt to the international behavioral norms and elevate their CER spending. Interestingly, our results provide partial support for our proposed moderating effect of marketization level. Although we see that marketization level negatively moderate the negative effects of family ownership on CER investment, meaning that family firms headquartered in provinces with higher marketization level do not invest less in CER when family ownership is high, the effect is approaching significance $(\beta=0.16, p<0.1)$. This suggests that although the institutional environment plays a key 
role in influencing family firms' CER initiatives, the external environmental pressure for privately held firms is not as salient as having investments from developed market venture capitals.

We find strong support $(\beta=0.28, p<0.05)$ for the negative moderating effect on the negative relationship between family ownership and CER investments when venture capital comes into play-the relationship is reversed —in that high family ownership leads to more CER spending with the introduction of venture capital investment. This showcases the strength of having high family ownership under specific circumstances. In this case, venture capitalists from developed markets represent opportunities for global expansion and heightened growth potential, and the increased level of competition in the global arena acts as a wakeup call on family managers to raise their bar on CER initiatives. When family ownership is concentrated, it is easier for the firm to reach consensus and follow the venture capital's lead to increase CER spending. Consistent with the literature drawing on agency-stakeholder theory, which states that family firms with concentrated ownership pay more attention to internal stakeholders than regulatory and market stakeholders when it comes to environmental management (Huang et al. 2009). Once venture capitalists take on equity stake within the firms, family managers consider them as internal stakeholders. Thus, they pay more attention towards their advice and suggestions, especially when compared to the marketization influences in the external institutional environment, which is considered to be external stakeholders and inevitable placed on the back burner.

The current study contributes to the existing literature in several ways. First, we offer insights to the literature on CER by examining the effect of family business ownership on environmental investment decisions. In a highly concentrated family ownership structure, very few external stakeholders are involved in management and governance. Moreover, the reputational and ethical pressure for environmental responsibility not as salient. Introducing shareholders such as venture capitals can provide a way for private firms to become aware of the needs of external stakeholders such as the environmental and institutional constituents. This effect is observed when venture capital investments come from more developed economies that have stricter CER standards and are more compliant to CER related regulations. Second, we answer the call for research on family business ethics (Vazquez 2018). In the context of private family firm behaviors regarding environmental responsibility, this study paves way for future studies to further dissect the relationship between family ownership and CER decisions. The majority of businesses in the world, both in developed and emerging economies, are privately owned family enterprises. Although the current study contributes to the school of thought that family ownership tend to focus on internal stakeholder needs, it is important to note that when external parties such as foreign venture capitals become involved, concentrated family ownership can provide the unity and decisiveness needed to quickly adapt to new ethical standards. By adapting the agency-stakeholder perspective (Hill and Jones 1992), the findings in this study suggest that private family firms with concentrated ownership are more likely to address the needs of external stakeholders (i.e., the environment and regulatory agencies) when investors such as venture capitalists from developed markets become internal stakeholders by taking up equity stakes. Finally, our paper contributes to the growing body of literature that focuses on the institutional environment and its effect on firm behaviors. Family firms that operate in more developed institutional environment likely receive more support to participate in CER activities and are under more pressure to spend more on CER in general. Our efforts answer the call for more context driven business research by focusing on an emerging market with the largest number of private family firms that has undergone drastic institutional changes in recent decades. The findings in this study also shed light on ways to promote CER spending in privately held family firms. Due to an internal stakeholder bias, institutional support and regulatory pressure from the business environment is not enough to drastically change family firms' CER spending. In addition to continuous marketization efforts, policy makers should foster and promote foreign investments opportunities, especially for family firms with concentrated ownership.

The findings in this study also have practical implications. As policy makers in emerging markets contemplate the environmental impact of business activities and create incentives for CER activities, it is 
crucial to pay close attention to the ownership structure of family firms. For wholly privately-owned domestic family firms, salient operational needs of the owning family are likely to take precedence over environmental concerns. To induce more participation and compliance in CER, incentives that highlight both short term and long-term benefits can be useful. The most effective intervention is to encourage venture capital investments from developed markets to increase the awareness of the necessity of CER as well as the norm of CER investment in the global arena. Another way to improve family firm CER investment is to continuously improve the institutional support provided in the business environment. It is possible that there are firms that wish to focus more on CER initiatives but are not able to obtain government grants to offset the economic costs. A more developed institutional environment is more equipped to give support and apply pressure to its local business community to participate in CER activities.

\section{Limitations and Direction for Future Studies}

Our study is not without limitations. Although we identify and quantify venture capital shareholding from developed markets, we do not have detailed information regarding each investment and its origin. The venture capitals included in our sample are mostly from Australia, Taiwan, and Hongkong, while a smaller percentage is from European countries and North America. While these markets have stricter CER requirements and standards, not all developed markets have the same level of institutional development and rules regarding CER. We do not know the exact level of institutional difference when comparing other places to each province in China. Future studies are encouraged to examine individual venture capital investments and explore the institutional distance between the investor and the location of the target family firm. This will provide a more nuanced understanding of how different venture capital investments influence family firm decision making.

Furthermore, our results do not take into account the unobservable CEO/family firm characteristics that could influence CER investments (Coles and Li 2016). Although we use family firm long term orientation as a proxy to control for family firm CER orientation (Block 2010; Block and Wagner 2010) and CEO status as a proxy to control for CEO CER orientation (Chatterjee and Hambrick 2007; Gerstner et al. 2013), we do not have direct measures on each family firm CEO's personal beliefs regarding CER. Since family firm CEOs often command significant personal influence and have control over all aspects of firm investment decision making process, future research could delve deeper into CEO beliefs and characteristics to enhance the current research framework. Along the same line, it is possible that an owning family's overall attitude toward environmental protection plays a significant role in attracting investors from developed markets due to the alignment of CER orientation. Therefore, future studies are encouraged to assess family firm's belief and propensity to invest in CER. We also recognize that family firms with higher corporate visibility and stronger brand reputation may naturally attract more foreign venture investments. While we control for brand reputation via CEO self-reported assessment vis-a-vis industry rivals, a more objective assessment is needed. We suggest that future studies further explore the effect of corporate reputation on both CER investment decisions and foreign investment.

The family firm data collected in this study also does not contain any detailed description of the compensation structure for executives and family members. While we know that our sampled firms hold $85 \%$ of equity on average, we cannot make any assumptions about the exact equity incentives for each family CEO. According to the research on managerial compensation (Core and Guay 1999), achieving an optimal equity incentive level could significantly affect CEO self-interested decision making. In addition, the current study does not have information regarding the corporate governance practice/structure of the sampled firms. Since privately held firms are not required to have a formal governance body (i.e., board of directors), we do not differentiate those that do. It is very likely that some firms operate and self-regulate in a fashion that is similar to publicly held firms while others do not have any formal codes or structure. Future studies could shed light on this topic by focusing on the corporate governance perspective. In particular, how does the existence of monitoring and regulating 
functions affect the relationship between family ownership and CER spending? If foreign venture capital investments translate to board seats, in addition to shareholding, do their interactions on the board affect CER activities? Future research is encouraged to conduct comparative studies between private and public firms both in emerging and developed economies to further examine governance factors that affect family firm CER decisions. Along these lines, we found evidence that suggests that good governance practices are more beneficial in non-competitive industries when compared to competitive industries (Giroud and Mueller 2008). Future studies could contribute to the corporate governance literature by revisiting the current research framework to explore under what industry conditions do privately held family firms in emerging markets benefit from good governance.

Author Contributions: The authors contributed equally to the manuscript. Conceptualization, Z.Z. and F.L.; methodology, F.L.; software, F.L.; validation, Z.Z. and F.L.; formal analysis, F.L.; investigation, F.L.; resources, F.L.; data curation, F.L.; writing—original draft preparation, Z.Z.; writing—review and editing, Z.Z.; visualization, F.L.; supervision, Z.Z.; project administration, Z.Z.; funding acquisition, F.L. All authors have read and agreed to the published version of the manuscript.

Funding: This research was funded by National Natural Science Foundation of China, No. 71702195.

Conflicts of Interest: The authors declare no conflict of interest.

\section{References}

Adams, Janet S., Armen Taschian, and Ted H. Shore. 1996. Ethics in family and non-family owned firms: An exploratory study. Family Business Review 9: 157-70. [CrossRef]

Aguilera, Ruth V., Deborah E. Rupp, Cynthia A. Williams, and Jyoti Ganapathi. 2007. Putting the S back in corporate social responsibility: A multilevel theory of social change in organizations. Academy of Management Review 32: 836-63. [CrossRef]

Anderson, Ronald C., and David M. Reeb. 2003. Founding-family ownership and firm performance: Evidence from the S\&P 500. The Journal of Finance 58: 1301-28.

Arora, Punit, and Ravi Dharwadkar. 2011. Corporate governance and corporate social responsibility (CSR): The moderating roles of attainment discrepancy and organization slack. Corporate Governance: An International Review 19: 136-52. [CrossRef]

Assimakopoulos, Margarita-Niki, Rosa Francesca De Masi, Filippo de Rossi, Dimitra Papadaki, and Silvia Ruggiero. 2020. Green Wall Design Approach towards Energy Performance and Indoor Comfort Improvement: A Case Study in Athens. Sustainability 12: 3772. [CrossRef]

Becker, Gary S., and Kevin M. Murphy. 1988. A theory of rational addiction. Journal of political Economy 96: 675-700. [CrossRef]

Bertrand, Marianne, and Antoinette Schoar. 2006. The role of family in family firms. Journal of Economic Perspectives 20: 73-96. [CrossRef]

Block, Jörn. 2010. Family management, family ownership and downsizing: Evidence from S\&P 500 firms. Family Business Review 23: 1-22.

Block, Jorn H., and Marcus Wagner. 2010. Corporate Social Responsibility in Large Family and Founder Firms. Erasmus Research Institute of Management Research Report No. ERS-2010-027-ORG. Amsterdam: Elsevier.

Cai, Peter. 2015. China's New Economic Crisis: Keeping the family business. The Asialink Essays 7: 3-4.

Campopiano, Giovanna, and Alfredo De Massis. 2015. Corporate social responsibility reporting: A content analysis in family and non-family firms. Journal of Business Ethics 129: 511-34. [CrossRef]

Casson, Mark. 1999. The economics of the family firm. Scandinavian Economic History Review 47: 10-23. [CrossRef]

Chan, Christine M., Shige Makino, and Takehiko Isobe. 2010. Does subnational region matter? Foreign affiliate performance in the United States and China. Strategic Management Journal 31: 1226-43. [CrossRef]

Chatterjee, Arijit, and Donald C. Hambrick. 2007. It's all about me: Narcissistic chief executive officers and their effects on company strategy and performance. Administrative Science Quarterly 52: 351-86. [CrossRef]

Coles, Jeffrey L., and Zhichuan Li. 2016. An Empirical Assessment of Empirical Corporate Finance. Business Publications 23. Available online: https://ir.lib.uwo.ca/iveypub/23 (accessed on 31 May 2020). [CrossRef]

Corbetta, Guido. 1995. Patterns of development of family businesses in Italy. Family Business Review 8: $255-65$. [CrossRef] 
Core, John, and Wayne Guay. 1999. The use of equity grants to manage optimal equity incentive levels. Journal of Accounting and Economics 28: 151-84. [CrossRef]

Coughlin, Cletus C., Joseph V. Terza, and Vachira Arromdee. 1991. State characteristics and the location of foreign direct investment within the United States. The Review of Economics and Statistics 73: 675-83. [CrossRef]

Cuervo-Cazurra, Alvaro, and Luis Alfonso Dau. 2009. Promarket reforms and firm profitability in developing countries. Academy of Management Journal 52: 1348-68. [CrossRef]

Davies, Howard, and Peter Walters. 2004. Emergent patterns of strategy, environment and performance in a transition economy. Strategic Management Journal 25: 347-64. [CrossRef]

Dawson, Alexandra. 2011. Private equity investment decisions in family firms: The role of human resources and agency costs. Journal of Business Venturing 26: 189-99. [CrossRef]

De Massis, Alfredo, Pramodita Sharma, Jess H. Chua, and James J. Chrisman. 2012. Family Business Studies: An Annotated Bibliography. Cheltenham Glos: Edward Elgar.

Déniz, María de la Cruz Déniz, and Ma Katiuska Cabrera Suárez. 2005. Corporate social responsibility and family business in Spain. Journal of Business Ethics 56: 27-41. [CrossRef]

Ding, Shujun, and Zhenyu Wu. 2014. Family ownership and corporate misconduct in US small firms. Journal of Business Ethics 123: 183-95. [CrossRef]

Donckels, Rik, and Erwin Frohlich. 1991. Are family businesses really different? European experiences from STRATOS. Family Business Review 4: 149-60. [CrossRef]

Duh, Mojca, Jernej Belak, and Borut Milfelner. 2010. Core values, culture and ethical climate as constitutional elements of ethical behaviour: Exploring differences between family and non-family enterprises. Journal of Business Ethics 97: 473-89. [CrossRef]

Dyck, Alexander, Karl V. Lins, Lukas Roth, and Hannes F. Wagner. 2019. Do institutional investors drive corporate social responsibility? International evidence. Journal of Financial Economics 131: 693-714. [CrossRef]

Fan, Gang, Xiaolu Wang, and Hengpeng Zhu. 2007. NERI Index of Marketization of China's Regions. Beijing: Economic Science Press.

Fan, Gang, Xiaolu Wang, and Hengpeng Zhu. 2011. NERI Index of Marketization of China's Provinces Report. Beijing: Economic Science Press.

Gallo, Miguel Angel. 1998. Ethics in personal behavior in family business. Family Business Review 11: 325-35. [CrossRef]

Gerstner, Wolf-Christian, Andreas König, Albrecht Enders, and Donald C. Hambrick. 2013. CEO Narcissism, audience engagement, and organizational adoption of technological discontinuities. Administrative Science Quarterly 58: 257-91. [CrossRef]

Ghaed, Shiva G., and Linda C. Gallo. 2007. Subjective social status, objective socioeconomic status, and cardiovascular risk in women. Health Psychology 26: 668. [CrossRef]

Giroud, Xavier, and Holger Mueller. 2008. Corporate Governance. In Product Market Competition, and Equity Prices, Working Paper. New York: New York University.

Gómez-Mejía, Luis R., Katalin Takács Haynes, Manuel Núñez-Nickel, Kathyrn J. L. Jacobson, and José Moyano-Fuentes. 2007. Socioemotional wealth and business risks in family-controlled firms: Evidence from Spanish olive oil mills. Administrative Science Quarterly 52: 106-37. [CrossRef]

Gomez-Mejia, Luis R., Cristina Cruz, Pascual Berrone, and Julio De Castro. 2011. The bind that ties: Socioemotional wealth preservation in family firms. Academy of Management Annals 5: 653-707. [CrossRef]

Graafland, Johan J., and Hugo Smid. 2004. Reputation, corporate social responsibility and market regulation. Tijdschrift voor Economie en Management XLIX: 271-308.

Guthrie, James P., and Judy D. Olian. 1991. Does context affect staffing decisions? The case of general managers. Personnel Psychology 44: 263-92. [CrossRef]

Harrison, Ann E., and Gunnar Eskeland. 2003. Moving to greener pastures? Multinationals and the pollution haven hypothesis. Journal of Development Economics 70: 1-23.

Harveston, Paula D., Peter S. Davis, and Julie A. Lyden. 1997. Succession planning in family business: The impact of owner gender. Family Business Review 10: 373-96. [CrossRef]

Hill, Charles W. L., and Thomas M. Jones. 1992. Stakeholder-agency theory. Journal of Management Studies 29: 131-54. [CrossRef]

Huang, Yi-Chun, Hung-Bin Ding, and Ming-Rea Kao. 2009. Salient stakeholder voices: Family business and green innovation adoption. Journal of Management \& Organization 15: 309-26. 
Ioannou, Ioannis, and George Serafeim. 2012. What drives corporate social performance? The role of nation-level institutions. Journal of International Business Studies 43: 834-64. [CrossRef]

Jensen, Michael C. 2001. Foundations of Organizational Strategy. Cambridge: Harvard University Press.

Jia, Nan. 2014. Are collective political actions and private political actions substitutes or complements? Empirical evidence from China's private sector. Strategic Management Journal 35: 292-315. [CrossRef]

Jiang, Liangliang, Chen Lin, and Ping Lin. 2014. The determinants of pollution levels: Firm-level evidence from Chinese manufacturing. Journal of Comparative Economics 42: 118-42. [CrossRef]

Kappes, Imke, and Thomas Schmid. 2013. The effect of family governance on corporate time horizons. Corporate Governance: An International Review 21: 547-66. [CrossRef]

Kotlar, Josip, and Alfredo De Massis. 2013. Goal setting in family firms: Goal diversity, social interactions, and collective commitment to family-centered goals. Entrepreneurship Theory and Practice 37: 1263-88. [CrossRef]

Li, Hongbin, Lingsheng Meng, Qian Wang, and Li-An Zhou. 2008. Political connections, financing and firm performance: Evidence from Chinese private firms. Journal of Development Economics 87: 283-99. [CrossRef]

Li, Zhichuan Frank, Saurin Patel, and Srikanth Ramani. 2020. The role of mutual funds in corporate social responsibility. Journal of Business Ethics. forthcoming. [CrossRef]

Lin, Tyrone T., Chuan-Chuan Ko, and Hsin-Ni Yeh. 2007. Applying real options in investment decisions relating to environmental pollution. Energy Policy 35: 2426-32. [CrossRef]

Lubatkin, Michael H., Yan Ling, and William S. Schulze. 2007. An organizational justice-based view of self-control and agency costs in family firms. Journal of Management Studies 44: 955-71. [CrossRef]

Nekhili, Mehdi, Haithem Nagati, Tawhid Chtioui, and Claudia Rebolledo. 2017. Corporate social responsibility disclosure and market value: Family versus nonfamily firms. Journal of Business Research 77: 41-52. [CrossRef]

Neter, John, William Wasserman, and Michael H. Kutner. 1985. Applied linear statistical models: Regression. In Analysis of Variance, and Experimental Designs, 2nd ed. Homewood: Richard D.

Niehm, Linda S., Jane Swinney, and Nancy J. Miller. 2008. Community social responsibility and its consequences for family business performance. Journal of Small Business Management 46: 331-50. [CrossRef]

Popescu, Cristina Raluca Gh, and Gheorghe N. Popescu. 2019. An exploratory study based on a questionnaire concerning green and sustainable finance, corporate social responsibility, and performance: Evidence from the Romanian business environment. Journal of Risk and Financial Management 12: 162. [CrossRef]

Popescu, Cristina Raluca, Gheorghe N. Popescu, and Veronica Adriana Popescu. 2017. Assessment of the State of Implementation of Excellence Model Common Assessment Framework (CAF) 2013 by the National Institutes of Research-Development-Innovation in Romania. Amfiteatru Economic 19: 41-60.

Pruthi, Sarika, Mike Wright, and Andy Lockett. 2003. Do foreign and domestic venture capital firms differ in their monitoring of investees? Asia Pacific Journal of Management 20: 175-204. [CrossRef]

Rees, William, and Tatiana Rodionova. 2015. The Influence of Family Ownership on Corporate Social Responsibility: An International Analysis of Publicly Listed Companies. Corporate Governance: An International Review 23: 184-202. [CrossRef]

Schulze, William S., Michael H. Lubatkin, Richard N. Dino, and Ann K. Buchholtz. 2001. Agency relationships in family firms: Theory and evidence. Organization Science 12: 99-116. [CrossRef]

Shi, Weilei, Sunny Li Sun, and Mike W. Peng. 2012. Sub-national institutional contingencies, network positions, and IJV partner selection. Journal of Management Studies 49: 1221-45. [CrossRef]

Shi, Weilei, Lívia Markóczy, and Ciprian V. Stan. 2014. The continuing importance of political ties in China. Academy of Management Perspectives 28: 57-75. [CrossRef]

Shi, Weilei Stone, Sunny Li Sun, Daying Yan, and Zhu Zhu. 2017. Institutional fragility and outward foreign direct investment from China. Journal of International Business Studies 48: 452-76. [CrossRef]

Slater, Daniel J., and Heather R. Dixon-Fowler. 2009. CEO international assignment experience and corporate social performance. Journal of Business Ethics 89: 473-89. [CrossRef]

Sun, Pei, Helen W. Hu, and Amy J. Hillman. 2016. The dark side of board political capital: Enabling blockholder rent appropriation. Academy of Management Journal 59: 1801-22. [CrossRef]

Szopik-Depczyńska, Katarzyna, Angelika Kędzierska-Szczepaniak, Krzysztof Szczepaniak, Katarzyna Cheba, Waldemar Gajda, and Giuseppe Ioppolo. 2018. Innovation in sustainable development: an investigation of the EU context using 2030 agenda indicators. Land Use Policy 79: 251-62. [CrossRef] 
Uhlaner, Lorraine M., HJM Annemieke van Goor-Balk, and Enno Masurel. 2004. Family business and corporate social responsibility in a sample of Dutch firms. Journal of Small Business and Enterprise Development 11: 186-94. [CrossRef]

Vazquez, Pedro. 2018. Family business ethics: At the crossroads of business ethics and family business. Journal of Business Ethics 150: 691-709. [CrossRef]

Wang, Dechun. 2006. Founding family ownership and earnings quality. Journal of Accounting Research 44: 619-56. [CrossRef]

Wang, Hua, and Yanhong Jin. 2002. Industrial Ownership and Environmental Performance: Evidence from China. Washington, DC: The World Bank.

Yin, Xunzhi, Qi Dong, Siyuan Zhou, Jiaqi Yu, Lu Huang, and Cheng Sun. 2020. Energy-Saving Potential of Applying Prefabricated Straw Bale Construction (PSBC) in Domestic Buildings in Northern China. Sustainability 12: 3464. [CrossRef]

$\mathrm{Yu}$, Andy, Hung-Bin Ding, and Hsi-Mei Chung. 2015. Corporate social responsibility performance in family and non-family firms: The perspective of socio-emotional wealth. Asian Business Management 14: 383-412. [CrossRef]

(C) 2020 by the authors. Licensee MDPI, Basel, Switzerland. This article is an open access article distributed under the terms and conditions of the Creative Commons Attribution (CC BY) license (http://creativecommons.org/licenses/by/4.0/). 